\title{
Bending properties of dimension lumber produced from Siberian larch (Larix sibirica) in Mongolia
}

\author{
Bayasaa Tumenjargal 1,2,3 ${ }^{1,}$ Futoshi Ishiguri ${ }^{*}$, Yusuke Takahashi ${ }^{1}$, Ikumi Nezu ${ }^{1}$, Bayartsetseg Baasan ${ }^{3}$, \\ Ganbaatar Chultem ${ }^{3}$, Haruna Aiso-Sanada ${ }^{4}$, Jyunichi Ohshima ${ }^{1}$ and Shinso Yokota ${ }^{1}$
}

\begin{abstract}
The modulus of elasticity (MOE) and modulus of rupture (MOR) were evaluated for 190 pieces of dimension lumber ( 2 by 4 lumber, 38 by $89 \mathrm{~mm}$ in cross-section) produced from Larix sibirica trees grown in Mongolia. The 5\% tolerance limits of the MOE and MOR were $5.70 \mathrm{GPa}$ and $15.1 \mathrm{MPa}$, respectively. The value of the $5 \%$ tolerance limit of the MOR exceeded the characteristic value of 2 by 4 lumber in visual grading class No. 3 of the Japanese Agricultural Standard for the D. fir-L, Hem-Tam, JS-III and S-P-F softwood species groups. A significant positive correlation was found between the MOE and MOR, although air-dry density was weakly correlated with bending properties in L. sibirica.
\end{abstract}

Keywords: Larix sibirica, Modulus of elasticity, Modulus of rupture, 5\% tolerance limit, Visual grading, Juvenile wood

\section{Introduction}

Structural lumber is one of the world's main construction materials, and graded lumber is the highest value product from trees [1]. When structural lumber is produced, the mechanical properties need to be assessed to ensure structural safety.

The mechanical properties of lumber vary considerably, because it is a natural material. Numerous studies have focused on mechanical properties, especially the modulus of elasticity (MOE) and modulus of rupture (MOR) in bending for structural lumber sawn from softwood species grown in plantations and natural forests [2-19]. Characteristic values, such as the lower tolerance limits of the MOE and MOR, are very important for structural lumber in construction [10,13, 20-22]. The 5th percentile ultimate stress value is used to calculate allowable design stress [4]. For example, França et al. [22] estimated allowable design bending strength for Southern pine (Pinus spp.) and found a value of $10.3 \mathrm{MPa}$ for 2 by 4

\footnotetext{
*Correspondence: ishiguri@cc.utsunomiya-u.ac.jp

1 School of Agriculture, Utsunomiya University, Utsunomiya,

Tochigi 321-8505, Japan

Full list of author information is available at the end of the article
}

lumber. Zhong and Ren [21] reported that design values for the bending strength of Larix gmelinii 2 by 4 lumber were 18.4 MPa for select structural (SS), 11.6 MPa for No. 1, 12.7 MPa for No. 2, and 10.3 MPa for No. 3 grade.

Sawing patterns in relation to the presence of juvenile wood have been investigated for softwood species [14, $16,17,19,20,23-25]$. Problems of juvenile wood used as structural lumber are derived from inferior mechanical properties and inconsistent stability compared to mature wood [3]. Matsumura et al. [23] examined the influence of the sawing patterns of lumber (center, inner, and outer) on dynamic Young's modulus in Japanese cedar (Cryptomeria japonica) logs and found the lowest values of the modulus of the lumber to be in both the center and inner positions that contained juvenile wood.

In Mongolia, Siberian larch (Larix sibirica Ledeb.) is a major softwood species, and wood from this species is mainly used for structural lumber in construction due to its high mechanical strength properties $[18,19,26]$. We previously examined the geographical variations of wood properties and the quality of dimension lumber ( 2 by 4 lumber) for L. sibirica collected from five different provenances in Mongolia. Significant differences were found in the wood and the bending properties of the lumber 
between the provenances [18, 27]. However, there are limited available data on the characteristic values of the bending properties of dimension lumber for this species grown in Mongolia.

The objectives of this study were to determine the $5 \%$ lower limit with a $75 \%$ confidence level of the bending properties of 2 by 4 lumber produced from $L$. sibirica trees in Mongolia. Differences in bending properties were also examined between the visual grading classes and different types of sawing pattern, and the relationships between the air-dry density and bending properties of the lumber were investigated.

\section{Materials and methods}

\section{Lumber production}

Figure 1 shows the experimental procedures used in the present study. A total of 111 logs were obtained from 25 trees (from 3 to 6 logs per tree) harvested from five different natural forests in Mongolia [18, 27]. The logs were sawn into as many 100 -by- $50 \mathrm{~mm}$ cross-sections as possible. A total of 190 pieces of lumber were thus obtained from the logs [18]. The lumber was air-dried in a laboratory without an air conditioner or heater in Ulaanbaatar, Mongolia, for 1 year, and the lumber was then planed into 38-by-89 $\mathrm{mm}$ cross-sections [18]. After planning, the lumber was classified into three types: lumber including pith at almost the center position in cross-section (I), lumber obtained near the pith (sometimes including pith on the surface area of the lumber) (II), and lumber obtained from the outer part of the logs (without pith) (III) (Fig. 1).

\section{Bending properties of lumber}

Before the bending test, the air-dry density at testing was determined by measuring the weight, length, and cross-section dimensions of the lumber using a portable electric balance (SL-20 K, A\&D), a laser measure (GLM50C, Bosch), and digital calipers (CD-15CX, Mitutoyo), respectively.

The bending test was conducted using a material testing machine (WDW-20E, Jinan Kason Testing Equipment). Load speed, support span, and distance between the load points were $14 \mathrm{~mm} / \mathrm{min}, 1602 \mathrm{~mm}$, and $534 \mathrm{~mm}$, respectively [18]. The specimen was set randomly on the supports. The load was applied in the edgewise direction. The MOE and MOR of the lumber were determined by the following equations:

$$
\operatorname{MOE}(\mathrm{GPa})=\frac{\Delta P\left(l-l^{\prime}\right)\left[3 l^{2}-2\left(l-l^{\prime}\right)^{2}\right]}{8 \Delta y b h^{3}}
$$

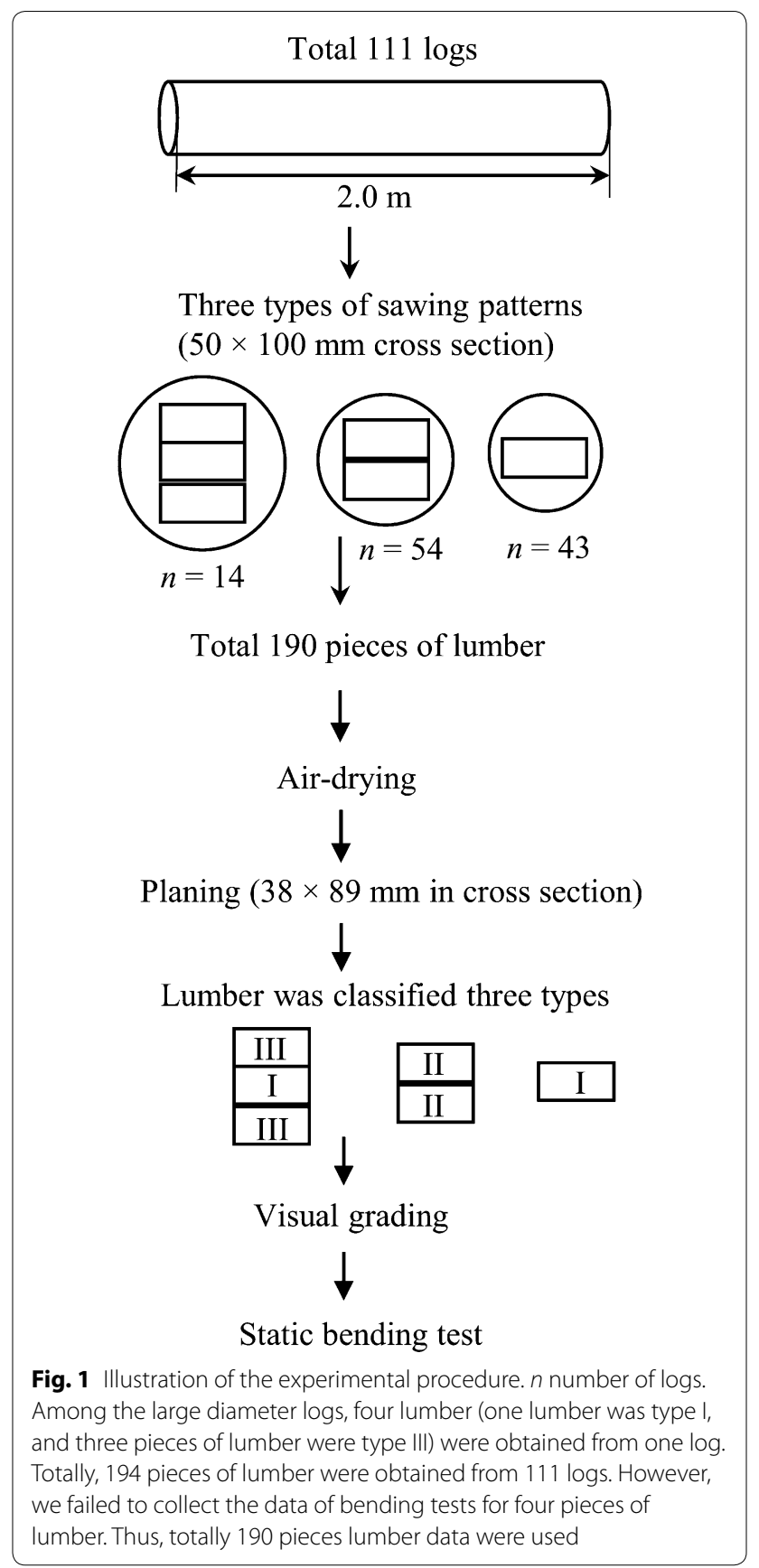

$$
\operatorname{MOR}(\mathrm{MPa})=\frac{3 P_{\max }\left(l-l^{\prime}\right)}{2 b h^{2}}
$$

where $\Delta P(\mathrm{~N})$ is the difference in load between 10 and $40 \%$ of the maximum load $\left(P_{\max }\right), \Delta y$ the difference in deflection corresponding to $\Delta P, l(\mathrm{~mm})$ the span, $l^{\prime}(\mathrm{mm})$ the difference between the load points, $b(\mathrm{~mm})$ the width of the specimen, and $h(\mathrm{~mm})$ the height of the specimen. 
After the bending test, small specimens $(2.5 \mathrm{~cm}$ in longitudinal direction) without any defects were obtained from the lumber. The specimens were used to measure the annual ring width and to determine the moisture content using an oven-drying method. The moisture content of the lumber was found to be $12.7 \pm 0.7 \%$. The MOE and MOR values were therefore adjusted to those at $15 \%$ moisture content using the following formula [28]:

$$
P_{2}=P_{1}(\alpha-\beta 15) /(\alpha-\beta M)
$$

where $P_{2}$ is the MOE or MOR value at a moisture content of $15 \%, P_{1}$ is the MOE or MOR value at testing, $M$ is the moisture content at testing, $\alpha$ is 1.44 and 1.75 for MOE and MOR, respectively, and $\beta$ is 0.0200 and 0.0333 for MOE and MOR, respectively.

\section{Visual grading}

All pieces of lumber were graded according to the Japanese Agriculture Standard (JAS) for structural lumber for wood frame construction [29]. For grading, the typical visual sorting criteria, such as annual ring width, knot size, existence and size of holes, slope of grain, deformation (bow, crook, and twist), wane, and crack, were measured on the surfaces of all pieces of lumber as described in the JAS. Based on the measurements, the lumber was classified into five grades (select structural, No. 1, No. 2, No. 3, and out grade) according to the JAS for structural lumber for wood frame construction.

\section{Data analysis}

Data analyses were conducted using Excel 2016 (Microsoft) and R [30] software. The 5\% lower tolerance limits with a $75 \%$ confidence level $\left(\mathrm{TL}_{75 \%, 95 \%}\right)$ of the MOE and MOR were calculated using the following formula [28]:

$$
\mathrm{TL}_{75 \%, 95 \%}=\mu-K \sigma
$$

where $\mu$ is the mean value, $K$ a constant $(1.7247, n=190)$, and $\sigma$ the standard deviation.

Significant differences in air-dry density, MOE, and MOR between the visual grades of three wood types were analyzed using the Tukey-HSD test at a 5\% significance level, and the relationships between the measured properties were determined using Pearson's correlation coefficient.

\section{Results and discussion Bending properties}

The statistical values of the annual ring width, air-dry density at testing (moisture content at $12.7 \pm 0.7 \%$ ), MOE, and MOR of the lumber are presented in Table 1. Annual ring width and air-dry density at testing ranged from 0.3 to $5.2 \mathrm{~mm}$ and 0.50 to $0.74 \mathrm{~g} / \mathrm{cm}^{3}$, respectively. The adjusted MOE and MOR mean values at $15 \%$ moisture content were $9.89 \mathrm{GPa}$ and $50.3 \mathrm{MPa}$, respectively.

Figure 2 shows the distributions of the MOE and MOR of lumber for $L$. sibirica in the present study. The distribution patterns for the MOE and MOR fit well to a normal distribution. The $5 \%$ tolerance limits were calculated using the mean and standard deviation and found to be 5.70 GPa and 15.1 MPa for the MOE and MOR, respectively (Table 1 ). In the present study, we compared the characteristic values of MOR in three species groups including Larix species (D. fir-L, Hem-Tam, and JS-III), and a major dimension lumber species group, S-P-F [31]. The value of the $5 \%$ tolerance limit of the MOR exceeded the characteristic value of the MOR of 2 by 4 lumber in visual grading class No. 3 of the JAS for structural lumber for wood frame construction for the D. firL, Hem-Tam, S-P-F species groups, and JS-III (Table 2). In addition, the MOR values of over $90 \%$ of the tested lumber in the present study fit the characteristic values of the MOR of 2 by 4 lumber in visual grading class No. 1 or upper grade of the JAS for the D. fir-L, Hem-Tam, S-P-F, and JS-III species groups [31] (Table 2). Furthermore, the $5 \%$ tolerance limit was also calculated in each visual grade, such as SS, SS + No.1, SS + No.1+No.2, and SS +No. $1+$ No. $2+$ No.3 (Table 3). The values of the $5 \%$ tolerance limit of the MOR in each grade were higher than characteristic values of the MOR of 2 by 4 lumber in visual grading class No. 3 in D. fir-L, Hem-Tam, S-P-F, and JS-III species groups.

\begin{tabular}{|c|c|c|c|c|c|c|}
\hline Properties & $n$ & Mean & SD & Max. & Min. & $\mathrm{TL}_{75 \%, 95 \%}$ \\
\hline ARW (mm) & 190 & 2.0 & 1.1 & 5.2 & 0.3 & - \\
\hline $\mathrm{AD}\left(\mathrm{g} / \mathrm{cm}^{3}\right)$ & 190 & 0.61 & 0.05 & 0.74 & 0.50 & - \\
\hline MOE (GPa) & 190 & 9.89 & 2.43 & 21.08 & 4.11 & 5.70 \\
\hline MOR (MPa) & 190 & 50.3 & 20.4 & 110.9 & 13.6 & 15.1 \\
\hline
\end{tabular}

Table 1 Mean statistical values of lumber properties in L. sibirica

Values of the MOE and MOR were adjusted to those at 15\% moisture content by the method of the Japan Housing and Wood Technology Center [28] $n$ number of lumber pieces, $A R W$ annual ring width, $A D$ air-dry density at testing (moisture content at $12.7 \pm 0.7 \%$ ), MOE modulus of elasticity, MOR modulus of rupture, $S D$ standard deviation, Max. maximum, Min. minimum, $\mathrm{TL}_{75 \%, 95 \%}, 5 \%$ lower limit with a $75 \%$ confidence level (5\% tolerance limit) 


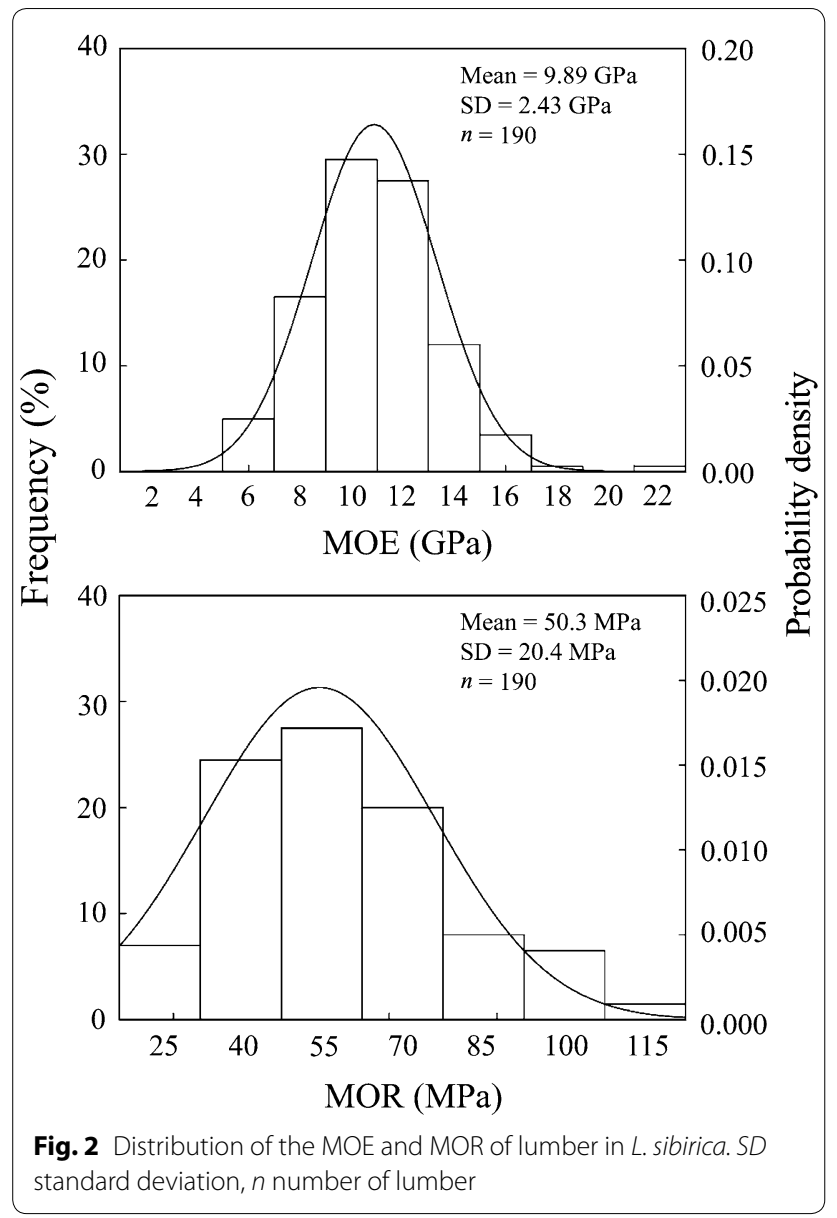

Based on the results, it is considered that dimension lumber produced from $L$. sibirica harvested from Mongolia has almost the same bending properties as that produced from other Larix species belonging to the D. fir-L Hem-Tam, and JS-III groups, such as L. occidentalis, $L$. gmelinii, L. kaempferi, and L. laricina.

\section{Visual grading}

The mean values of the air-dry density, MOE, and MOR of the lumber in each visual grade are listed in Table 4. According to visual grading based on the JAS for structural lumber for wood frame construction, $56.8 \%(n=108), 6.3 \% \quad(n=12), 10 \% \quad(n=19), 10.5 \%$ $(n=20)$, and $16.3 \%(n=31)$ of the pieces of lumber were graded as SS, No. 1, No. 2, No. 3, and out grade, respectively. Zhou et al. [15] analyzed the mechanical properties of visually graded 2 by 4 lumber for $L$. gmelinii and reported that the highest MOE (10.16 $\mathrm{GPa}$ ) and MOR (38.4 MPa) values were found in SS grade and the lowest in No. 3 grade $(\mathrm{MOE}=8.45 \mathrm{GPa}$ and $\mathrm{MOR}=19.6 \mathrm{MPa}$ ). In addition, Zhong and Ren [21] evaluated the bending strength of 2 by 4 lumber for $L$. gmelinii and found that the mean value of the MOR for SS grade was $65.1 \mathrm{MPa}$, which was higher than those of other grades. Similar results were also found in lumber for 50-, 73-, and 90-year-old Pinus banksiana [10]. In the present study, the highest mean values of the MOE and MOR were found in No. 1 grade (10.90 GPa and 54.2 $\mathrm{MPa}$, respectively) and the lowest in out grade lumber (8.38 GPa and $40.2 \mathrm{MPa}$, respectively). No significant differences in either the MOE or MOR were found between SS, No. 1, No. 2, and No. 3 grade lumber, while the MOE and MOR in out grade lumber showed notably lower values (Table 4). These results indicate that visual grading for dimension lumber produced in this species is effective for eliminating lumber with extremely low strength properties, such as out grade. In addition, downgrading factors in the visual grading were evaluated for lumber (Table 5). Among evaluated factors, annual ring width, fiber orientation, and crack were not considered as downgrading factors in the visual grading class. On the other hand, knot, wane, and twist were major defects to downgrade for visual grading class in this species (Table 5).

Table 2 Characteristic value of the MOR in $\mathbf{2}$ by $\mathbf{4}$ lumber and the number of $L$. sibirica lumber in each grade

\begin{tabular}{|c|c|c|c|c|c|c|c|c|c|c|c|c|}
\hline \multirow[t]{3}{*}{ Grade } & \multicolumn{4}{|c|}{$\begin{array}{l}\text { Characteristic value of MOR in } 2 \text { by } 4 \text { lumber } \\
\text { (MPa) }\end{array}$} & \multicolumn{8}{|c|}{ Number of $L$. sibirica lumber in characteristic value of MOR for each grade } \\
\hline & \multirow[t]{2}{*}{ D. fir-L } & \multirow[t]{2}{*}{ Hem-Tam } & \multirow[t]{2}{*}{ S-P-F } & \multirow[t]{2}{*}{ JS-III } & \multicolumn{2}{|c|}{ D. fir-L } & \multicolumn{2}{|c|}{ Hem-Tam } & \multicolumn{2}{|c|}{ S-P-F } & \multicolumn{2}{|c|}{ JS-III } \\
\hline & & & & & No. & $\%$ & No. & $\%$ & No. & $\%$ & No. & $\%$ \\
\hline SS & 36.0 & 29.4 & 30.0 & 22.5 & 139 & 73.2 & 163 & 85.8 & 160 & 84.2 & 180 & 94.7 \\
\hline No. 1 & 24.6 & 18.0 & 22.2 & 16.1 & 38 & 20.0 & 21 & 11.1 & 21 & 11.1 & 5 & 2.6 \\
\hline No. 2 & 21.6 & 13.8 & 21.6 & 15.5 & 6 & 3.2 & 5 & 2.6 & 2 & 1.1 & 2 & 1.1 \\
\hline No. 3 & 12.6 & 8.4 & 12.6 & 9.0 & 7 & 3.7 & 1 & 0.5 & 7 & 3.7 & 3 & 1.6 \\
\hline
\end{tabular}

Characteristic values of the MOR in 2 by 4 lumber were cited from "Matters to determine the standard strength of wood $F_{c^{\prime}} F_{t^{\prime}} F_{b^{\prime}}$ and $F_{s}$ " in Notification of Ministry of Land, Infrastructure, Transport and Tourism No. 910 [31]. Species group D. fir-L includes L. occidentalis, L. gmelinii, Pseudotsuga menziesii, and others; group HemTam includes L. kaempferi, L. laricina, and others; and group S-P-F includes Picea engelmannii, Pinus sylvestris, Abies balsamea, and others; and group JS-III includes L. kaempferi and similar species

SS select structural 
Table 3 Mean values, standard deviations, and $5 \%$ lower tolerance limits of each grade

\begin{tabular}{|c|c|c|c|c|c|c|c|}
\hline \multirow[t]{2}{*}{ Grade } & \multirow[t]{2}{*}{$n$} & \multicolumn{3}{|c|}{ MOE (GPa) } & \multicolumn{3}{|c|}{ MOR (MPa) } \\
\hline & & Mean & SD & $\mathrm{TL}_{75 \%, 95 \%}$ & Mean & SD & $\mathrm{TL}_{75 \%, 95 \%}$ \\
\hline SS & 108 & 10.08 & 2.43 & 5.83 & 52.8 & 21.9 & 14.4 \\
\hline SS + No. 1 & 120 & 10.17 & 2.41 & 5.96 & 52.9 & 21.6 & 15.1 \\
\hline $\mathrm{SS}+$ No. $1+$ No. 2 & 139 & 10.19 & 2.42 & 5.99 & 52.8 & 21.5 & 15.4 \\
\hline $\mathrm{SS}+\mathrm{No} .1+\mathrm{No} .2+\mathrm{No} .3$ & 159 & 10.18 & 2.40 & 6.01 & 52.3 & 20.7 & 16.4 \\
\hline
\end{tabular}

$n$ number of lumber, $M O E$ modulus of elasticity, MOR modulus of rupture, SD standard deviation, $S S$ select structural, $\mathrm{TL}_{75 \%, 95 \%}, 5 \%$ lower limit with a $75 \%$ confidence level ( $5 \%$ tolerance limit)

Table 4 Mean values and standard deviations of the air-dry density and bending properties of lumber in each visual grade

\begin{tabular}{|c|c|c|c|c|c|c|c|}
\hline \multirow[t]{2}{*}{ Grade } & \multirow[t]{2}{*}{$n$} & \multicolumn{2}{|c|}{$A D\left(g / \mathrm{cm}^{3}\right)$} & \multicolumn{2}{|c|}{ MOE (GPa) } & \multicolumn{2}{|c|}{ MOR (MPa) } \\
\hline & & Mean & SD & Mean & SD & Mean & SD \\
\hline SS & 108 & $0.60^{a}$ & 0.05 & $10.08^{a}$ & 2.43 & $52.8^{\mathrm{a}}$ & 21.9 \\
\hline No. 1 & 12 & $0.63^{\mathrm{a}}$ & 0.06 & $10.90^{\mathrm{a}}$ & 2.16 & $54.2^{\mathrm{ab}}$ & 19.8 \\
\hline No. 2 & 19 & $0.61^{\mathrm{a}}$ & 0.05 & $10.37^{\mathrm{a}}$ & 2.56 & $52.1^{\mathrm{ab}}$ & 21.1 \\
\hline No. 3 & 20 & $0.60^{\mathrm{a}}$ & 0.04 & $10.07^{\mathrm{ab}}$ & 2.35 & $48.8^{\mathrm{ab}}$ & 14.4 \\
\hline Out grading & 31 & $0.60^{\mathrm{a}}$ & 0.04 & $8.38^{b}$ & 2.00 & $40.2^{b}$ & 14.9 \\
\hline
\end{tabular}

The same letters ( $\mathrm{a}$ and $\mathrm{b}$ ) followed by mean values indicate no significance at the $5 \%$ level according to the Tukey-HSD test

$n$ number of lumber pieces, $A D$ air-dry density, $M O E$ modulus of elasticity, MOR modulus of rupture, $S D$ standard deviation, $S S$ select structural

Table 5 Downgrading factors in the visual grading of lumber

\begin{tabular}{lrrrr}
\hline Factor & \multicolumn{4}{l}{$\begin{array}{l}\text { Quantity of downgraded lumber in each } \\
\text { grade (\%) }\end{array}$} \\
\cline { 2 - 5 } & SS & No. 1 & No. 2 & No. 3 \\
\hline Knot & 28.4 & 20.5 & 16.8 & 8.4 \\
ARW & 0.0 & 0.0 & 0.0 & 0.0 \\
Wane & 15.3 & 15.3 & 10.0 & 8.9 \\
Fiber orientation & 0.0 & 0.0 & 0.0 & 0.0 \\
Crack & 0.0 & 0.0 & 0.0 & 0.0 \\
Crook & 2.6 & 2.6 & 0.0 & 0.0 \\
Bow & 2.1 & 2.1 & 1.1 & 0.0 \\
Twist & 10.0 & 10.0 & 4.2 & 2.1 \\
\hline
\end{tabular}

Mean values were calculated from the ratio of the lumber downgraded to total lumber. Total lumber $=190$

$A R W$ annual ring width, $S S$ select structural

Effects of lumber type on bending properties

Butler et al. [16] reported that significant differences between lumber with pith and without pith were found in the MOE and MOR of 2 by 4 lumber in Pinus taeda. Dahlen et al. [20] also reported that the MOE and MOR of lumber ( 2 by 6,2 by 8,2 by 10 , and 2 by 12 ) with pith were significantly lower than those of lumber without pith in Southern pine (Pinus spp.). In addition, the lumber obtained from the center of logs had lower strength classes than side lumber from Pseudotsuga menziesii trees $[14,17]$. In the present study, $30 \%$ of the lumber overall $(n=57)$ was classified into type I lumber (Table 6). Mean values ranged from 9.28 to $10.15 \mathrm{GPa}$ and from 43.2 to $57.4 \mathrm{MPa}$ for the MOE and MOR, respectively, among the three lumber types. Although the mean value of the MOE for type I lumber was lower than those for types II and III, no significant differences were found among these types. The MOR of type I lumber was significantly lower than those of types II and III. These results suggest that lumber with pith has lower bending properties. In previous reports, we examined the effect of juvenile wood on the properties of 2 by 4 lumber in L. kaempferi and found significant differences between juvenile wood and mature wood in bending properties [19]. Shivnarain and Smith [3] reported that the percentage of juvenile wood in a piece of lumber is a good indicator of bending strength in 2 by 4 lumber from Picea glauca trees. Based on these results, the MOE and MOR of L. sibirica lumber are considered to be greatly affected by the presence of juvenile wood. Thus, when structural $L$. sibirica lumber that requires higher strength properties is needed, the sawing pattern should be carefully considered in lumber production. 
Table 6 Mean values and standard deviations of lumber properties in each sawing pattern

\begin{tabular}{|c|c|c|c|c|c|c|c|c|c|}
\hline \multirow[t]{2}{*}{ Lumber type } & \multirow[t]{2}{*}{$n$} & \multicolumn{2}{|c|}{ ARW (mm) } & \multicolumn{2}{|c|}{$A D\left(g / \mathrm{cm}^{3}\right)$} & \multicolumn{2}{|c|}{ MOE (GPa) } & \multicolumn{2}{|c|}{ MOR (MPa) } \\
\hline & & Mean & SD & Mean & SD & Mean & SD & Mean & SD \\
\hline I & 57 & $2.1^{\mathrm{a}}$ & 1.1 & $0.59^{\mathrm{a}}$ & 0.05 & $9.28^{\mathrm{a}}$ & 2.21 & $43.2^{\mathrm{a}}$ & 12.5 \\
\hline$\|$ & 104 & $2.0^{\mathrm{a}}$ & 1.1 & $0.60^{\mathrm{a}}$ & 0.04 & $10.15^{\mathrm{a}}$ & 2.36 & $52.3^{b}$ & 21.4 \\
\hline III & 29 & $1.9^{\mathrm{a}}$ & 1.2 & $0.65^{b}$ & 0.04 & $10.14^{\mathrm{a}}$ & 2.92 & $57.4^{b}$ & 25.2 \\
\hline
\end{tabular}

The same letters ( $a$ and $b$ ) followed by mean values indicate no significance at the $5 \%$ level according to the Tukey-HSD test. The values of the MOE and MOR were adjusted to the values at $15 \%$ moisture content

$n$ number of lumber pieces, $A R W$ annual ring width, $A D$ air-dry density at testing, $M O E$ modulus of elasticity, MOR modulus of rupture, $S D$ standard deviation, $/$ lumber including pith at an almost-center position in cross-section, II lumber obtained near the pith (sometimes including pith on the surface area of the lumber), III lumber obtained from outer part of the logs (without pith)

Table 7 Correlation coefficients between properties

\begin{tabular}{lrrrl}
\hline $\begin{array}{l}\text { Grade } \\
\text { and lumber } \\
\text { types }\end{array}$ & $\boldsymbol{n}$ & AD-MOE & AD-MOR & MOE-MOR \\
\hline Total lumber & 190 & $0.182^{*}$ & $0.215^{* *}$ & $0.789^{* *}$ \\
SS & 108 & $0.302^{* *}$ & $0.302^{* *}$ & $0.801^{* *}$ \\
No. 1 & 12 & $0.196^{\mathrm{ns}}$ & $0.196^{\mathrm{ns}}$ & $0.910^{* *}$ \\
No. 2 & 19 & $-0.090^{\mathrm{ns}}$ & $0.021^{\mathrm{ns}}$ & $0.760^{* *}$ \\
No. 3 & 20 & $0.222^{\mathrm{ns}}$ & $-0.064^{\mathrm{ns}}$ & $0.613^{* *}$ \\
Out grading & 31 & $-0.014^{\mathrm{ns}}$ & $-0.076^{\mathrm{ns}}$ & $0.762^{* *}$ \\
I & 57 & $0.122^{\mathrm{ns}}$ & $-0.057^{\mathrm{ns}}$ & $0.635^{* *}$ \\
II & 104 & $0.180^{\mathrm{ns}}$ & $0.249^{*}$ & $0.814^{* *}$ \\
III & 29 & $0.196^{\mathrm{ns}}$ & $0.106^{\mathrm{ns}}$ & $0.879^{* *}$ \\
\hline
\end{tabular}

For abbreviations, refer to Tables 2 and 4

ns not significant

* Significant at the $5 \%$ level; ${ }^{* *}$ significant at the $1 \%$ level

\section{Correlations between lumber properties}

Correlation coefficients between the air-dry density and bending properties of lumber are listed in Table 7. With a few exceptions, no significant correlations were found between the air-dry density and the MOE or MOR. Although air-dry density showed significant relationships with both the MOE and MOR overall and in SS grade lumber, the correlation coefficients were lower. Similar weak correlation coefficients between density and MOR were found in L. kaempferi lamina $(r=0.242)$ [32], and 2 by 4 lumber of $C$. japonica $(r=0.094)$ [13]. In addition, the relationships between wood density and MOR might be affected by presence of large amounts of arabinogalactan in the species. In the previous study [26], we reported that arabinogalactan might be included in hotwater extracts in heartwood of $L$. sibirica, and the content of hot-water extracts was $14.1 \%$. Thus, it is considered that wood density including arabinogalactan in this species resulted in overestimation of wood density values. Cáceres et al. [33] examined the influence of extractives on wood density in L. kaempferi; they found that the hot-water extractive content (mainly arabinogalactan) of L. kaempferi varied between 2.9 and 6.9\%. Therefore, the presence of large amounts of arabinogalactan might result in lower correlation coefficients between air-dry density and bending properties. Based on the results, air-dry density is considered not to be a good predictor of the bending properties of visually graded lumber in $L$. sibirica.

Significant positive correlation coefficients were found between the MOE and MOR in all types of lumber (Table 7). Gupta et al. [8] found a positive relationship between the MOE and MOR of L. dahurica 2 by 4 lumber. Butler et al. [16] also found a significantly positive correlation coefficient between the MOE and MOR of loblolly pine (Pinus taeda) lumber. In addition, significantly positive correlations were observed between the MOE and MOR of 2 by 4 lumber from Picea glauca [6] and both green and dry 2 by 8 lumber from three different softwood species [4]. The results obtained in this study suggest that the MOE of lumber is a good predictor of MOR in L. sibirica.

\section{Conclusions}

The bending properties of 2 by 4 lumber from L sibirica in Mongolia were investigated in this study. The mean values of MOE and MOR adjusted to $15 \%$ moisture content were $9.89 \mathrm{GPa}$ and $50.3 \mathrm{MPa}$, respectively. The $5 \%$ tolerance limits of these properties were $5.70 \mathrm{GPa}$ and 15.1 $\mathrm{MPa}$, respectively. The value of the $5 \%$ tolerance limit of the MOR exceeded the characteristic value of the MOR of 2 by 4 lumber in visual grading class No. 3 of the JAS for structural lumber for wood frame construction for D. fir-L, Hem-Tam, JS-III, and S-P-F species groups. The mean MOR values were significantly higher in the lumber obtained from the outer part of the logs. A significant positive correlation was found between the MOE and MOR, although the air-dry density was weakly correlated with bending properties. 


\section{Abbreviations}

MOE: Modulus of elasticity; MOR: Modulus of rupture; $\mathrm{TL}_{75 \%, 95 \%}$ : $5 \%$ lower tolerance limit with a $75 \%$ confidence level; SS: Select structural.

\section{Acknowledgements}

The authors thank Ms. Yui Kobayashi and Mr. Tappei Takashima (students at Utsunomiya University), and Mr. Sarkhad Murzabek and Ms. Togtokhbayar Erdene-Ochir (Mongolian University of Science and Technology) for their assistance in measuring the lumber properties.

\section{Authors' contributions}

BT contributed to experiments, data analysis, and writing the manuscript. Fl designed this study and contributed to experiments, data analysis, and writing the manuscript. YT and IN contributed to experiments and data analysis. BB and GC contributed to experiments. HA-S, JO, and SY contributed to discussion on the obtained results. All authors read and approved the final manuscript.

\section{Funding}

A part of this research was financially supported by the M-JEED program of the Ministry of Education, Culture, Science, and Sports, Mongolia.

\section{Availability of data and materials}

Not applicable.

\section{Ethics approval and consent to participate}

The wood samples used in the present study were collected with the observance of Mongolian laws.

\section{Consent for publication}

Not applicable.

\section{Competing interests}

The authors declare that they have no competing interests.

\section{Author details}

1 School of Agriculture, Utsunomiya University, Utsunomiya, Tochigi 321-8505, Japan. ${ }^{2}$ United Graduate School of Agricultural Science, Tokyo University of Agriculture and Technology, Fuchu, Tokyo 183-8509, Japan. ${ }^{3}$ Training and Research Institute of Forestry and Wood Industry, Mongolian University of Science and Technology, Ulaanbaatar 14191, Mongolia. ${ }^{4}$ Forestry and Forest Products Research Institute, Tsukuba, Ibaraki 305-8687, Japan.

Received: 10 December 2019 Accepted: 27 February 2020 Published online: 07 March 2020

\section{References}

1. Ramage MN, Burridge H, Busse-Wicher M, Fereday G, Reynolds T, Shah DU, Wu G, Yu L, Fleming P, Densley-Tingley D, Allwood J, Dupree P, Linden PF, Scherman O (2017) The wood from the trees: the use of timber in construction. Renew Sustain Energy Rev 68:333-359

2. lijima Y (1983) The mechanical properties of the Siberian larch wood Bull Toyama Wood Prod Res Inst 1:1-39 (In Japanese with English summary)

3. Shivnaraine CS, Smith I (1990) Influence of juvenile wood on bending properties of softwood lumber. J For Eng 1:25-33

4. Green DW, Kretschmann DE (1991) Lumber property relationships for engineering design standards. Wood Fiber Sci 23:436-456

5. Green DW, Kretschmann DE (1997) Properties and grading of Southern pine timer. For Prod J 47(9):78-85

6. Zhou H, Smith I (1991) Factors influencing bending properties of White spruce lumber. Wood Fiber Sci 23:483-500

7. Chui YH, MacKinnon-Peters G (1995) Wood properties of exotic larch grown in eastern Canada and north-eastern United States. For Chron 71:639-645

8. Gupta R, Ethington RL, Green DW (1996) Mechanical stress grading of Dahurian larch structural lumber. For Prod J 46(7/8):79-86

9. Ethington RL, Gupta R, Green WD (1997) Visual stress grades of Dahurian larch lumber. For Prod J 47(1):82-88
10. Duchesne I (2006) Effect of rotation age on lumber grade yield, bending strength and stiffness in Jack pine (Pinus banksiana Lamb.) natural stands. Wood Fiber Sci 38:84-94

11. Ishiguri F, Matsui R, lizuka K, Yokota S, Yoshizawa N (2008) Prediction of the mechanical properties of lumber by stress-wave velocity and Pilodyn penetration of 36-year-old Japanese larch trees. Holz Roh Werkstoff 66:275-280

12. Ishiguri F, Iki T, Otsuka K, Takahashi Y, Nezu I, Tumenjargal B, Ohshima J, Yokota S (2019) Wood and lumber properties of Larix gmelinii var. olgensis planted in Japan. BioResources 14:8072-8081

13. Shiiba A, Aratake S, Fujimoto Y, Oda H, Matsumoto A (2012) Mechanical performance of sugi (Cryptomeria japonica) wooden frame-construction lumber and evaluation of stress grading. Mokuzai Gakkaishi 58:90-99 (In Japanese with English summary)

14. Rais A, Poschenrieder W, Pretzsch H, van de Kuilen JG (2014) Influence of initial plant density on sawn timber properties for Douglas-fir (Pseudotsuga menziesii (Mirb.) Franco). Ann For Sci 71:617-626

15. Zhou H, Han L, Ren H, Ju J (2015) Size effect on strength properties of Chinese larch dimension lumber. BioResources 10:3790-3797

16. Butler MA, Dahlen J, Daniels RF, Eberhardt TL, Antony F (2016) Bending strength and stiffness of loblolly pine lumber from intensively managed stands located on the Georgia Lower Coastal Plain. Eur J Wood Prod 74:91-100

17. Filipescu CN, Stoehr MU, Pigott DR (2018) Variation of lumber properties in genetically improved full-sib families of Douglas-fir in British Columbia, Canada. Forestry 91:320-326

18. Tumenjargal B, Ishiguri F, Aiso-Sanada H, Takahashi Y, Nezu I, Baasan B, Chultem G, Ohshima J, Yokota S (2019) Geographic variation of lumber quality of Larix sibirica naturally grown in five different provenances of Mongolia. J Wood Sci 65:43

19. Tumenjargal B, Ishiguri F, Ohshima J, lizuka K, Otsuka K, Kinomoto M, Yokota S (2019) Effect of radial growth tare on wood and lumber properties of 67-year-old Japanese larch (Larix kaempferi) trees planted in Tochigi, Japan. Wood Fiber Sci 53:264-275

20. Dahlen J, Jones PD, Seale RD, Shmulsky R (2014) Bending strength and stiffness of wide dimension southern pine no. 2 lumber. Eur J Wood Prod 72:759-768

21. Zhong Y, Ren H (2014) Reliability analysis for the bending strength of larch 2 × 4 lumber. BioResources 9:6914-6923

22. França TSFA, França FJN, Seale RD, Shmulsky R (2018) Bending strength and stiffness of no. 2 grade Southern Pine lumber. Wood Fiber Sci 50:205-219

23. Matsumura Y, Murata K, Ikami Y, Matsumura J (2012) Influence of sawing patterns on lumber quality and yield in large sugi (Cryptomeria japonica) logs. For Prod J 62:25-31

24. Tanabe J, Ishiguri F, Nakayama M, Ohshima J, lizuka K, Yokota S (2016) Properties of juvenile and mature wood and their effects on the bending properties of lumber in Pinus taeda growing in Tochigi, Japan. For Prod J 66:428-432

25. Nagao H, Washino K, Kato H, Tanaka T (2003) Estimation of timber strength based on the distribution of MOE in the stem, application to Japanese larch. Mokuzai Gakkaishi 49:59-67 (In Japanese with English summary)

26. Ishiguri F, Tumenjargal B, Baasan B, Jigjjiv A, Pertiwi YAB, Aiso-Sanada H, Takashima Y, Iki T, Ohshima J, lizuka K, Yokota S (2018) Wood properties of Larix sibirica naturally grown in Tosontsengel, Mongolia. Inter Wood Prod J 9:127-133

27. Tumenjargal B, Ishiguri F, Aiso-Sanada H, Takahashi Y, Baasan B, Chultem G, Ohshima J, Yokota S (2018) Geographic variation of wood properties of Larix sibirica naturally grown in Mongolia. Silva Fenn. https://doi.org/10.14214/sf.10002

28. Japan Housing and Wood Technology Center (2011) Kouzouyoumokuzai no kyoudoshiken manual (Manual of strength testing for structural lumber). www.howtec.or.jp/files/libs/1828/201712121507021978.pdf. Accessed 6 Oct 2019 (In Japanese)

29. MAFF (2018). https://www.maff.go.jp/j/jas/jas_kikaku/attach/pdf/kikak u_itiran2-237.pdf. Accessed 4 Feb 2020 (In Japanese)

30. R Core Team (2018) R: A language and environment for statistical computing. R Foundation for Statistical Computing, Vienna, Austria. https:// www.R-project.org/. Accessed 1 Feb 2019 
31. Japan $2 \times 4$ Lumber JAS Council (2020). https://www.2x4lumber.jp/about /04.html. Accessed 20 Jan 2020

32. Hashizume T, Yoshida T, Takeda T, Ishihara S (1998) Properties of laminae from a planted Japanese larch tree, and the mechanical properties of glued laminated timber IV. Mokuzai Gakkaishi 44:49-58 (In Japanese with English summary)

33. Cáceres CB, Hernández RE, Fortin Y, Beaudoin M (2017) Wood density and extractive content variation among Japanese larch (Larix kaempferi
[Lamb.] Carr.) progenies/provenances trials in eastern Canada. Wood Fiber Sci 49:363-373

\section{Publisher's Note}

Springer Nature remains neutral with regard to jurisdictional claims in published maps and institutional affiliations.

\section{Submit your manuscript to a SpringerOpen ${ }^{\circ}$ journal and benefit from:}

- Convenient online submission

- Rigorous peer review

- Open access: articles freely available online

- High visibility within the field

- Retaining the copyright to your article

Submit your next manuscript at $\boldsymbol{\nabla}$ springeropen.com 